\title{
PENERAPAN DATA MINING UNTUK ANALISIS MARKET BASKET DENGAN ALGORITME FP-GROWTH PADA PD PASAR TOHAGA
}

\author{
Rusnandi ${ }^{1}$, Suparni ${ }^{2}$, Achmad Baroqah Pohan ${ }^{3}$ \\ ${ }^{1}$ Sistem Informasi, STMIK Nusa Mandiri \\ Jakarta, Indonesia \\ ${ }^{2}$ Administrasi Bisnis, Universitas Bina Sarana Informatika \\ Jakarta, Indonesia \\ ${ }^{3}$ Sistem Informasi, Universitas Bina Sarana Informatika \\ Jakarta, Indonesia

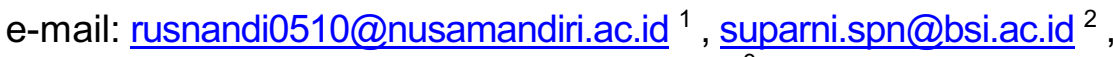 \\ achmad.abq@bsi.ac.id ${ }^{3}$
}

\begin{abstract}
Abstrak
Hasil dari data penjualan di 3 toko yang berbeda pada PD Pasar Tohaga yang selalu berupa buku transaksi hanya dilihat tanpa adanya tindak lanjut untuk menentukan keputusan di waktu yang akan datang. Pihak pemilik hanya mencatat transaksi produk yang terjual dan hanya melihat pendapatan perharinya. Padahal dengan data tersebut seharusnya dapat dimanfaatkan untuk menyusun strategi penjualan di waktu yang akan datang. Dengan menggunakan Metode Frequent Pattern Growth, pihak toko dapat mengambil keputusan barang mana yang membutuhkan persediaan yang lebih banyak dibandingkan dengan barang yang lain, dan peletakan barang yang sesuai dengan hubungan antar barang yang biasanya dibeli konsumen juga dapat ditentukan berdasarkan Minimum Support dan Minimum Confidence. Berdasarkan Market Basket Analysis yang diperoleh dari perhitungan asosiasi dengan menggunakan Metode Frequent Pattern Growth kemudian untuk pencarian nilai support dan confidence menggunakan Association Rules dan Rules yang dihasilkan akan diuji dengan menggunakan Software RapidMiner. Dengan menggunakan Metode Frequent Pattern Growth dan Association Rules maka penempatan barang dan persediaan barang di 3 toko yang berbeda dapat terkontrol dengan baik sehingga pelayanan pada konsumen akan meningkat yang pada akhirnya dapat meningkatkan omset penjualan. Dalam penelitian ini nilai Support ditentukan menggunakan ambang batas $40 \%$ dan Confidence $83 \%$. Dengan memperhatikan hubungan nilai support dan confidence pemilik toko dapat menyediakan dan menempatkan barang yang akan dijual secara tepat. Dari hasil penelitian ini didapatkan konsumen banyak membeli produk dengan merk converse dan cenderung akan membeli produk adidas. selain itu konsumen juga banyak menyukai produk dengan mrek carvil dan cenderung akan membeli produk rafila.
\end{abstract}

Kata kunci: Data mining, Association Rules, Market Basket Analysis, Frequent Pattern Growth

\begin{abstract}
Sales data in 3 different shops at Tohaga Market in the form of PD book transactions are only seen in the absence of follow-up to determine the decision on who will come. Party owner only records the transactions of products sold and only see income per month. But with that data should be utilized to strategize on sales to come. By using the method of Frequent Pattern Growth Algorithm, the store can take decisions which require goods inventory more compared to other goods, and the placement of the goods in accordance with the relationship between the goods that are usually purchased a consumer can also be determined based on a Minimum Support and Minimum Confidence. Based on Market Basket Analysis obtained from the calculation of the Association by using the method of Frequent Pattern Growth Algorithm, then search for the value of the support and confidence to use Association Rules, Rules that are generated will be test by using Software RapidMiner.
\end{abstract}


Then the placement of goods and inventory items in 3 different stores can be controlled with either the service so that the consumer will be increased, which in turn can increase the sales turnover. In this study Support is determined using threshold $40 \%$ and $83 \%$ Confidence. Having regard to the relationship of support and confidence the store owner can provide and put the items to be sold. the results of this study found that consumers buy more products with the converse brand and tend to buy adidas products. other than that consumers also prefer Carvil products and tend to buy raffila products

Keywords : Data mining, Association Rules, Market Basket Analysis, Frequent Pattern Growth

\section{PENDAHULUAN}

PD Pasar Tohaga merupakan perusahaan plat merah (BUMD) yang bergerak di bidang pasar tradisional/pasar rakyat, salah satu pasar yang dikelola adalah Pasar Citeureup 1 terletak di kecamatan citeureup kabupaten bogor yang merupakan tempat bertemunya penjual dan pembeli serta ditandai dengan adanya transaksi pembelian secara langsung dan biasanya ada proses tawar-menawar, bangunan biasanya terdiri dari kios-kios atau gerai, los dan dasaran terbuka yang dibuat oleh penjual maupun suatu pengelola pasar. Kebanyakan menjual kebutuhan sehari-hari seperti bahan-bahan makanan berupa ikan, buah, sayur-sayuran, telur daging, kain pakaian, barang-barang elektronik, sepatu dan sandal. Selain itu, ada pula yang menjual kue-kue dan barang-barang lainnya. Dengan begitu banyaknya data transaksi yang terjadi dalam setiap harinya pemilik toko di PD Pasar Toga belum menata rapih dapat pengolahan data penjualannya. Pada buku catatan transaksi penjualan sepatu dan sandal tidak dipisahkan. Sehingga sulit untuk mengetahui produk mana yang lebih unggul, sehingga menyebabkan terjadinya penumpukan barang yang tidak terlalu laku untuk dijual, bila sudah terjadi penumpukan berlebihan biasanya pemilik toko sepatu dan sandal di PD Pasar Tohaga menjual produk dengan harga modal yang hanya mendapatkan keuntungan kecil dan apabila masih tidak laku terjual pemilik toko sepatu dan sandal melakukan pemusnahan barang.

\section{Identfikasi Masalah}

Berdasarkan latar belakang yang sudah diuraikan di atas maka dapat di ambil identifikasi masalah sebagai berikut:
A. Bagaimana pola pembelian konsumen pada produk sepatu dan sandal di Pasar Citeureup 1 yang dikelola oleh PD Pasar Tohaga?

B. Bagaimana interpretasi dari pola pembelian yang dihasilkan menjadi sebuah informasi?

C. Bagaimana menerapkan Metode Data Mining dengan FP-GROWTH dalam menemukan sebuah produk yang diminati konsumen?

\section{Tujuan}

Tujuan dari penelitian ini adalah sebagai berikut:

A. Untuk menghasilkan knowledge (pengetahuan) tentang pola pembelian konsumen pada pembelian produk sepatu dan sandal di Pasar Citeureup 1 yang dikelola oleh PD Pasar Tohaga.

B. Untuk mengklasifikasi 3 toko di Pasar Citeureup 1 yang dikelola oleh PD Pasar Tohaga dalam menemukan sebuah informasi tentang Produk sepatu dan sandal yang diminati konsumen.

C. Dengan FP-GROWTH diharapkan dapat membantu dalam menentukan produk sepatu dan sandal yang diminati konsumen.

\section{Ruang Lingkup}

A. Pengambilan Data di 3 Toko yang berbeda diantaranya(Toko Reka, Toko Fernando dan Toko Son).

B. Data yang diambil mulai dari bulan Agustus 2018 sampai dengan Juli 2019.

C. Metode Perhitungan menggunakan Metode Frequent Pettern Growth (FPGrowth) dan Association Rules.

D. Pengujian hasil perhitungan menggunakan Aplikasi RapidMiner 5. 


\section{Landasan Teori}

Knowledge discovery in Database

Knowledge discovery in Database (KDD) didefinisikan sebagai ekstraksi informasi potensial, implisit dan tidak dikenal dari sekumpulan data. Proses knowledge discovery melibatkan hasil dari proses Data Mining (proses mengekstrak kecenderungan pola suatu data), kemudian mengubah hasilnya secara akurat menjadi informasi yang mudah dipahami. KDD sendiri diartikan sebagai keseluruhan proses non-trivial untuk mencari dan mengidentifikasi pola (pattern) dalam data, dimana pola yang ditemukan bersifat sah, baru, dapat bermanfaat dan dapat dimengerti[1].

\section{Market Basket Analysis (MBA)}

MBA merupakan suatu metodologi untuk melakukan analisis buying habit konsumen dengan menemukan asosiasi antar beberapa jenis barang yang berbeda, yang diletakkan konsumen dalam shopping basket yang dibeli pada suatu transaksi tertentu [2].

\section{Frequent Pattern-Tree (FP-Tree)}

FP-Tree merupakan struktur penyimpanan data yang dimanfaatkan. $F P$ tree dibangun dengan memetakan setiap data transaksi ke dalam setiap lintasan tertentu dalam FP-tree [3].

\section{Frequent Pattern-Growth (FP-Growth)}

Frequent Pattern Growth (FP-Growth) merupakan salah satu alternatif yang dapat digunakan untuk menentukan himpunan data yang paling sering muncul (frequent itemset) dalam sebuah kumpulan data.

Metode FP-Growth dapat dibagi menjadi 3 tahapan utama [4], diantaranya:

\section{A. Tahap Pembangkitan conditional pattern base}

Conditional Pattern Base merupakan subdatabase yang berisi prefix path (lintasan prefix) dan suffix pattern (pola akhiran). Pembangkitan conditional pattern base didapatkan melalui FP-tree yang telah dibangun sebelumnya.

B. Tahap pebangkitan conditional FP-Tree
Pada tahap ini, support count dari setiap item pada setiap conditional pattern base dijumlahkan, lalu setiap item yang memiliki jumlah support count lebih besar sama dengan minimum support count $\xi$ akan dibangkitkan dengan conditional FP-tree

C. Tahap pencarian frequent itemset
Apabila
Conditional
FP-tree merupakan lintasan tunggal (single path), maka didapatkan frequent itemset dengan melakukan kombinasi item untuk setiap conditional FP-tree. Jika bukan lintasan tunggal, maka dilakukan pembangkitan $F P$ growth secara rekursif.

\section{Association Rule Mining}

Association rules merupakan salah satu Metode yang bertujuan mencari pola yang sering muncul di antara banyak transaksi permintaan, dimana setiap permintaan terdiri dari beberapa item sehingga Metode ini akan mendukung Analisa permintaan barang melalui penemuan pola antar item dalam setiap permintaan barang yang terjadi [5].

Terdapat dua tahap dalam Association Rule Mining yaitu

\section{A. Frequent Itemset Generation.}

Tahapan ini bertujuan untuk mencari semua itemset yang memenuhi ambang batas minsup. Itemset tersebut disebut sebagai itemset frekuen (itemset yang sering muncul).

\section{B. Rule Generation.}

Tahapan ini bertujuan untuk mengekstrak aturan dengan confidance tinggi dari itemset Frekuen yang ditemukan dalam tahapan sebelumnya. Aturan yang didapatkan pada tahapan ini selanjutnya disebut sebagai aturan yang kuat (strong rule).

Metodologi dasar Association Rule terbagi menjadi dua tahap yaitu:

\section{A. Analisa Pola Frekuensi Tinggi}

Tahap ini mencari pola item yang memenuhi syarat minimum dari nilai support dalam database. Nilai support sebuah item diperoleh dengan rumus berikut: 


$$
\begin{aligned}
& \text { Support (A) } \\
& =\frac{\text { Jumlah transaksi mengandung A }}{\text { Total transaksi }}
\end{aligned}
$$

Pada rumus 1 menjelaskan bahwa nilai Support diperoleh dengan cara mencari jumlah transaksi yang mengandung nilai $A$ (satu item) dibagi dengan jumlah keseluruhan transaksi. Sedangkan nilai support dari 2 item diperoleh dari rumus berikut:

$$
\begin{aligned}
& \text { Support }(A \cap B) \\
& =\frac{\text { Transaksi mengandung A dan B }}{\text { Total transaksi }}
\end{aligned}
$$

Pada rumus 2 menjelaskna bahwa nilai support diperoleh dengan cara mencari jumlah transaksi yang mengandung nilai $A$ dan B (item pertama bersamaan dengan item yang lain) dibagi dengan keseluruhan transaksi.

B. Pembentukan Aturan Asosiatif

$$
\begin{aligned}
& \text { Confidence }=P(B \backslash A)=\frac{P(A \cap B)}{P(A)} \\
& =\frac{\text { Transaksi mengandung A dan } \mathrm{B}}{\text { Transaksi mengandung } \mathrm{A}}
\end{aligned}
$$

Pada rumus penjelasan bahwa nilai confiden diperoleh dengan cara mencari jumlah transaksi yang mengandung nilai $A$ dan B (item pertama bersamaan dengan item yang lain) dibagi dengan jumlah transaksi yang mengandung $\mathrm{A}$ (item pertama).

\section{METODE}

\section{Tahapan Penelitian}

Dari langkah-langkah yang harus dilalui agar penelitian ini bisa berjalan dengan baik.

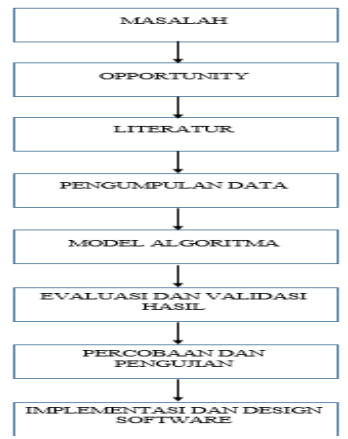

Gambar 2 Tahapan Penelitian
A. Masalah

Masalah Yang diindentifikasi dalam penelitian ini bertujuan untuk mengetahui pola pembelian konsumen dalam produk sepatu dan sandal di Pasar Citeureup 1 yang dikelola oleh PD Pasar Tohaga

\section{B. Opportunity}

Pada Tahapan ini, peluang yang dimaksud dari hasil penelitian terdahulu dengan menggunakan FP-Growth pada Pola Pembelian Konsumen.

\section{Literatur}

Literature yang dipakai sebagai bahan referensi dalam penelitian ini adalah Jurnaljurnal ilmiah, modul pembelajaran dan buku tentang Data Mining. Literatur-literatur ini menjadi pedoman untuk melakukan penelitian agar memudahkan proses penelitian.

\section{Pengumpulan Data}

Metode pengumpulan data, data yang diambil dari bulan agustus 2018 sampai dengan juli 2019 di 3 toko yang berbeda, diantaranya: Toko Reka, Toko Fernando dan Toko Son yang terdiri dari 48 merk populasi produk sepatu dan sandal yang berbeda selama 12 bulan.

\section{E. Model Algoritme}

Pada Tahapan ini, model Algoritme menggunakan Frequen Pattern Growth (FPGrowth) yang menghasilkan Frequent itemset dari Conditional Generation.

\section{F. Evaluasi dan Validasi Hasil}

Pada tahap ini hasi dari Conditional Generation akan dievaluasi dan validasi hasil. Evaluasi dan Validasi Hasil menggunakan Association Rules yang dimaksud dilakukan melalui mekanisme perhitungan Support dan Confidence. Dari suatu hubungan item. Sebuah rules asosiasi dikatakan interesting jika nilai support lebih besar dari nilai minimum support dan juga nilai confidence lebih besar dari nilai minimum confidence.

\section{G. Percobaan dan Pengujian}


Pada tahap ini, data transaksi penjualan dites kembali atau diuji lagi menggunakan System Data Mining yang sudah ada. Tools yang digunakan sebagai pengujian system adalah Rapidminer 5 .

H. Implementasi

Implementasi merupakan Prototype Fp-growth berbasis website dengan menggunakan database Mysql, Rancangan tampilan menggunakan Sublime Text dan Server menggunakan Xampp.

\section{Populasi}

Dalam penelitian ini, yang menjadi populasinya adalah merk produk sepatu dan sandal yang ada di buku transaksi pada 3 toko yang berbeda yang telah disatukan selama Agustus 2018 sampai dengan Juli 2019, dengan jumlah 48 merk sepatu dan sandal.

Tabel 1 Data Transaksi 3 Toko

\begin{tabular}{|c|c|c|c|}
\hline \multirow[b]{2}{*}{ Bulan } & \multicolumn{2}{|c|}{ Data Transaksi 3 Toko } & \multirow[b]{2}{*}{ Jumlah } \\
\hline & Kode & Produk & \\
\hline \multirow[t]{9}{*}{ Agustus 2018} & B1 & Adidas & 28 \\
\hline & & Rafila & 30 \\
\hline & & Ando & 28 \\
\hline & & New Era & 29 \\
\hline & & Carvil & 39 \\
\hline & & Romero & 17 \\
\hline & & Glass & 26 \\
\hline & & Ardiles & 23 \\
\hline & & Delta & 17 \\
\hline \multirow[t]{8}{*}{ September 2018} & B2 & Dallas & 13 \\
\hline & & Ando & \\
\hline & & Nike & 28 \\
\hline & & Pinard & 21 \\
\hline & & Pro Att & 14 \\
\hline & & Yumenda & \\
\hline & & Speace & 25 \\
\hline & & Kodaci & 32 \\
\hline \multirow{7}{*}{ Oktober 2018} & в3 & Adidas & 16 \\
\hline & & New Era & 18 \\
\hline & & Converse & 27 \\
\hline & & Fila & 11 \\
\hline & & Ardiles & 17 \\
\hline & & B.one & 16 \\
\hline & & Sankyo & 12 \\
\hline \multirow[t]{9}{*}{ November, 2018} & B4 & Rafila & 19 \\
\hline & & Ando & 18 \\
\hline & & Carvil & 11 \\
\hline & & Vans & 14 \\
\hline & & Jaguar & 16 \\
\hline & & $\begin{array}{l}\text { Pro Att } \\
\text { Prots }\end{array}$ & 26 \\
\hline & & Speed & 25 \\
\hline & & Kodaci & 16 \\
\hline & & Sankyo & 17 \\
\hline \multirow[t]{7}{*}{ Desember, 2018} & B5 & Adidas & 12 \\
\hline & & Dallas & 38 \\
\hline & & New Era & 23 \\
\hline & & Converse & 23 \\
\hline & & Delta & 17 \\
\hline & & Balance & 11 \\
\hline & & Nerro & 45 \\
\hline \multirow{8}{*}{ January, 2019} & B6 & Dallas & 27 \\
\hline & & Rafila & 26 \\
\hline & & Nike & 21 \\
\hline & & Carvil & 11 \\
\hline & & Ardiles & 23 \\
\hline & & Inkayni & 11 \\
\hline & & Lubrene & 14 \\
\hline & & Sankyo & 19 \\
\hline \multirow{6}{*}{ Februari, 2019} & B7 & Adidas & 49 \\
\hline & & Dallas & $\begin{array}{l}49 \\
37\end{array}$ \\
\hline & & Converse & 47 \\
\hline & & $\begin{array}{l}\text { Levis } \\
\text { List }\end{array}$ & 48 \\
\hline & & Yumenda & 24 \\
\hline & & Lubrene & 37 \\
\hline \multirow[t]{7}{*}{ Maret, 2019} & B8 & Rafila & 31 \\
\hline & & $\begin{array}{l}\text { Ando } \\
\text { Ando }\end{array}$ & 25 \\
\hline & & Carvil & 12 \\
\hline & & Vans & 57 \\
\hline & & Pinard & 34 \\
\hline & & Yumenda & 38 \\
\hline & & Tinker Bell & 20 \\
\hline
\end{tabular}

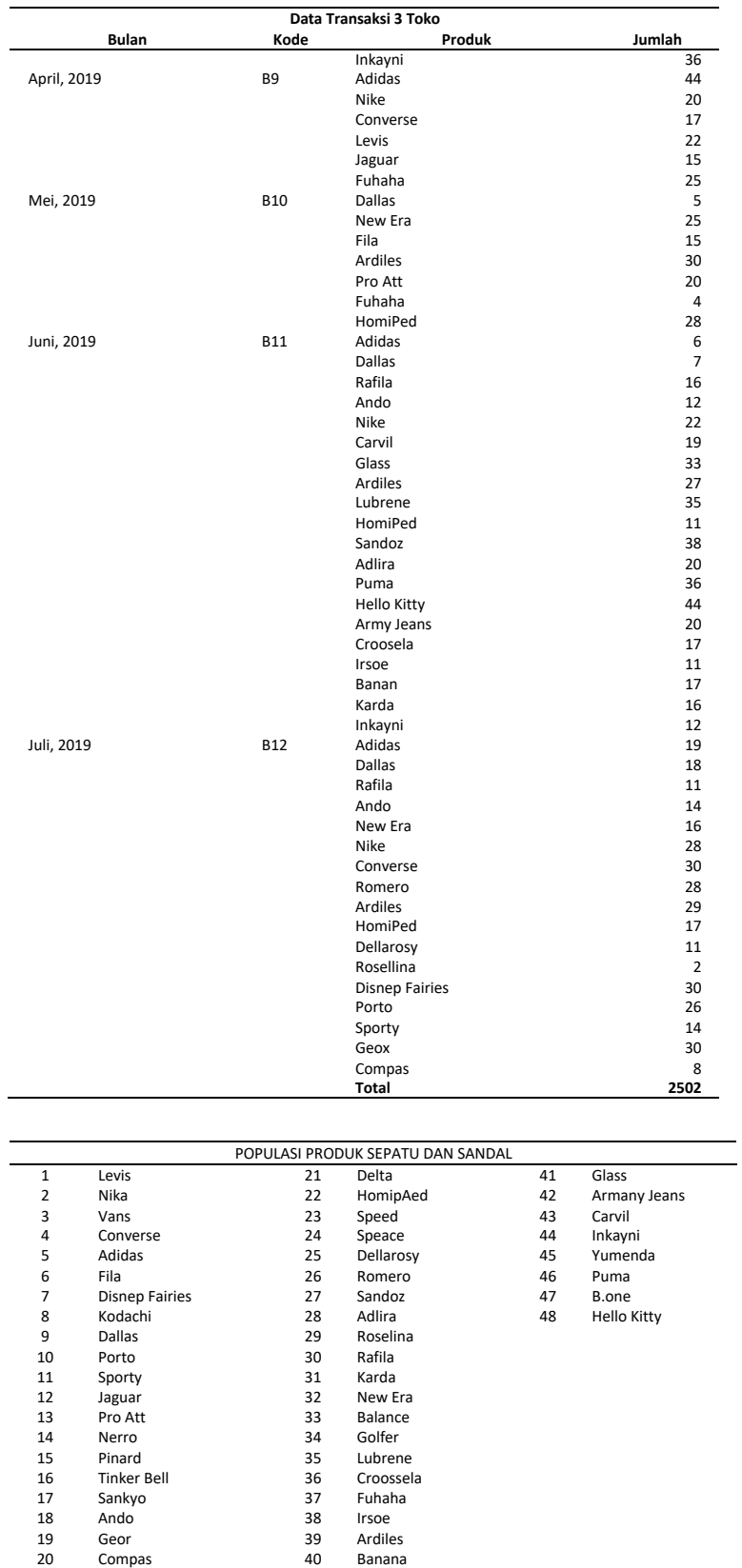

\section{Sampel Penelitian}

Dalam pengambilan sampel, jumlah 48 merk sepatu dan sandal dari hasil penggabungan buku transaksi di 3 toko yang berbeda, diantaranya toko reka, toko Fernando dan toko son yang bisa dilihat pada tabel 1 Data Transaksi 3 toko.

Agar diperoleh jumlah sampel yang lebih akurat menggunakan rumus slovin untuk menentukan besarnya sampel. Jumlah sampel ditentukan dengan tabel Isaac dan Michael dengan tingkat kesalahan adalah sebesar $10 \%$.

$$
\text { Rumus Slovin }=\frac{\mathrm{N}}{1+\mathrm{Ne}^{2}}(4)
$$


Keterangan:

$\mathrm{N}=$ Jumlah Total Populasi

$\mathrm{n}=$ Jumlah Sampel

$\mathrm{e}=$ Batas Toleransi Error

Perhitungan:

$n=\frac{48}{\left(1+48\left(0.1^{2}\right)\right)}$

$n=\frac{48}{(1+48(0.01)}$

$n=\frac{48}{(1+(48 \times 0.01))}$

$n=\frac{48}{(1+0.48)}$

$n=\frac{48}{1.48}$

$\mathrm{n}=32.43$ dibulatkan menjadi 33

Kemudian untuk pengambilan sample menggunakan teknik Sample Random Sampling yaitu teknik untuk mendapatkan sampel yang langsung dilakukan unit sampling. Dengan demikian setiap unit sampling sebagai unsur populasi yang terpencil memperoleh peluang yang sama untuk dijadikan sampel atau untuk mewakili populasi.

Berdasarkan hasil dari perhitungan menggunakan rumus slovin diatas, sampel yang diambil adalah 33 merk Sepatu dan Sandal yang disatukan dari 3 toko yang berbeda dengan Metode Simple Random Sampling.

Tabel 2 Sampel Merk Produk

\begin{tabular}{clllll}
\hline \multicolumn{5}{c}{ Nama Produk } \\
\hline 1 & Adidas & 12 & Levis & 23 & HomiPed \\
2 & Dallas & 13 & Jaguar & 24 & Yumenda \\
3 & Ando & 14 & Lubrene & 25 & Speed \\
4 & Ardiles & 15 & Pinard & 26 & Speace \\
5 & Rafila & 16 & Fila & 27 & Tinker Bell \\
6 & Carvil & 17 & Romero & 28 & Kodaci \\
7 & Converse & 18 & Glass & 29 & Bone \\
8 & New Era & 19 & Dellarosy & 30 & Delta \\
9 & Nike & 20 & Roselina & 31 & Inkayni \\
10 & Vans & 21 & Balance & 32 & Sankyo \\
11 & Pro Att & 22 & Fuhaha & 33 & Nerro \\
\hline
\end{tabular}

\section{Model Analisa}

Metode analisa data yang digunakan dalam penelitian ini adalah $F P$-Growth yang merupakan struktur data yang digunakan adalah tree disebut FP-Tree. Dengan menggunakan FP-Tree, FP-Growth dapat langsung mengekstrak frequent itemset dari $F P$-Tree. Penggalian itemset yang frequent dengan menggunakan FP-Growth akan dilakukan dengan cara membangkitkan struktur data tree atau disebut dengan FP. Tree.

Metode FP-Growth dapat dibagi menjadi 3 tahapan utama yaitu:

\section{A. Tahap pembangkitan Conditional Pattern Base \\ Conditional Pattern Base merupakan} subdatabase yang berisi prefix path (lintasan prefix) dan suffix pattern (pola akhiran). Pembangkitan conditional pattern base didapatkan melalui FP-tree yang telah dibangun sebelumnya.

B. Tahap pembangkitan Conditional FPTree.

Pada tahap ini, support count dari setiap item pada setiap conditional pattern base dijumlahkan, lalu setiap item yang memiliki jumlah support count lebih besar sama dengan minimum support count $\xi$ akan dibangkitkan dengan conditional FP-tree.

C. Tahap pencarian Frequent Itemset.
Apabila
Conditional
FP-tree

merupakan lintasan tunggal (single path), maka didapatkan frequent itemset dengan melakukan kombinasi item untuk setiap conditional FP-tree. Jika bukan lintasan tunggal, maka dilakukan pembangkitan FPgrowth secara rekursif.

\section{Kerang Pemikiran}

Kerangka pemikiran penelitian ini bisa dilihat pada gambar berikut.

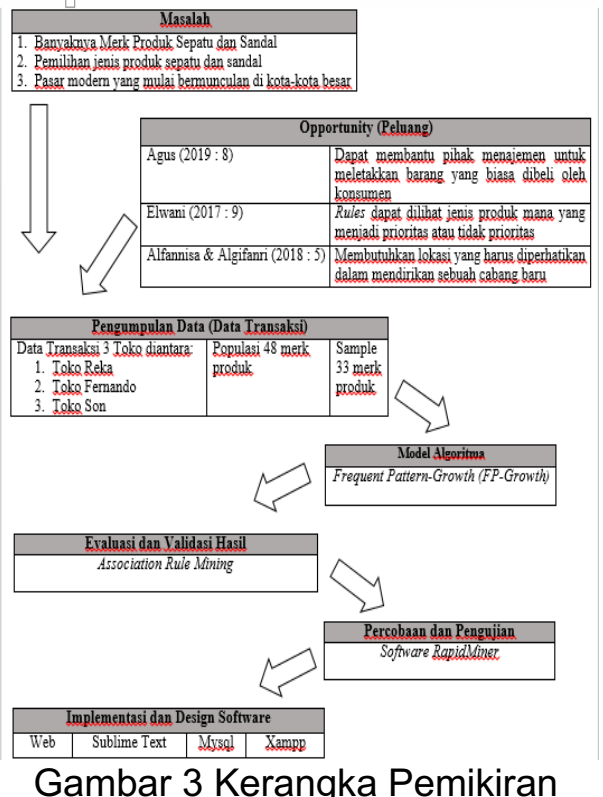

Gambar 3 Kerangka Pemikiran 


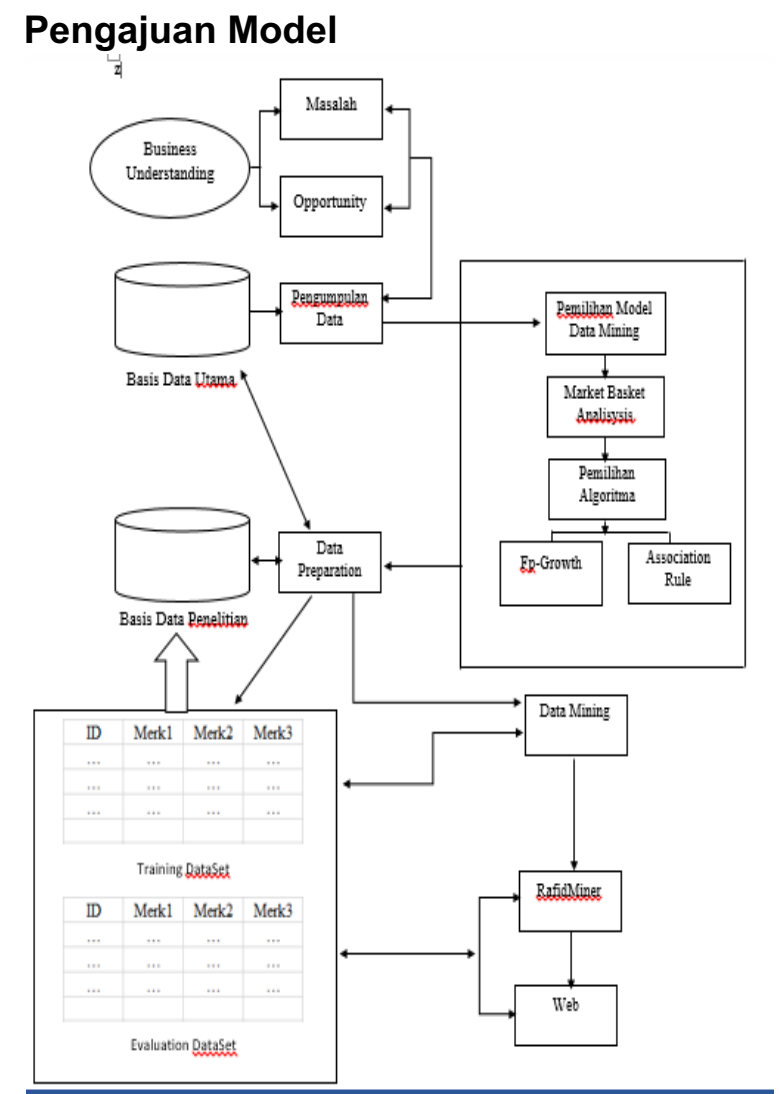

Gambar 4 Model Pengajuan

Pada gambar diatas, Model yang di ajukan tentang Market Basket Analysis, meliputi:
A. Masalah
B. Opportunity
C. Pengumpulan Data
D. Pemilihan Model Data Mining
E. Pemilihan
F. Data Preparation
G. Data Mining
H. RafidMiner
I. Web

\section{HASIL DAN PEMBAHASAN}

Dalam penelitian ini, pengumpulan data transaksi diperoleh dari buku catatan transaksi pada Toko Reka, Toko Fernando dan Toko Son yang kemudian digabungkan dan direkam menjadi data transaksi dengan menggunakan microsoft excel untuk selanjutkan diolah. Tahapan selanjutkan menerapkan FP-Growth pada data transaksi dan menggunakan association rule. Untuk nilai minimum support 0.40 atau sama dengan $40 \%$ dan confidence 0.83 atau sama dengan $83 \%$. Sehingga data support dan confidence yang tampil hanya memenuhi persyaratan tersebut

\section{Sample Data}

Berdasarkan hasil dari perhitungan menggunakan rumus slovin, dari 48 merk produk sepatu dan sandal, sampel yang diambil adalah 33 merk produk sepatu dan sandal yang disatukan dari 3 toko yang berbeda dengan Metode Simple Random Sampling.

Tabel 3 Data Selection

\begin{tabular}{clllll}
\multicolumn{5}{c}{ Nama Produk } \\
\hline 1 & Adidas & 12 & Levis & 23 & HomiPed \\
2 & Dallas & 13 & Jaguar & 24 & Yumenda \\
3 & Ando & 14 & Lubrene & 25 & Speed \\
4 & Ardiles & 15 & Pinard & 26 & Speace \\
5 & Rafila & 16 & Fila & 27 & Tinker Bell \\
6 & Carvil & 17 & Romero & 28 & Kodaci \\
7 & Converse & 18 & Glass & 29 & B.one \\
8 & New Era & 19 & Dellarosy & 30 & Delta \\
9 & Nike & 20 & Roselina & 31 & Inkayni \\
10 & Vans & 21 & Balance & 32 & Sankyo \\
11 & Pro Att & 22 & Fuhaha & 33 & Nerro \\
\hline
\end{tabular}

Setelah ditentukan 33 merk produk yang terpilih, langkah selanjutnya pola transaksi dengan menganalisis 33 merk produk yang paling banyak terjadi setiap bulannya.

Tabel 4 Sampel Transaksi

\begin{tabular}{|c|c|}
\hline Bulan & Produk \\
\hline 1 & $\begin{array}{l}\text { Addidas, Rafila, Ando, New Era, Carvil, } \\
\text { Romero, Glass, Ardiles, Delta }\end{array}$ \\
\hline 2 & $\begin{array}{l}\text { Dallas, Ando, Nike, Pinard, Pro Att, Yumenda, } \\
\text { Space, Kodaci }\end{array}$ \\
\hline 3 & $\begin{array}{l}\text { Adidas, New Era, Converse, Fila, Ardiles, } \\
\text { B.one, Sankyo }\end{array}$ \\
\hline 4 & $\begin{array}{l}\text { Rafila, Ando, Carvil, Vans, Jaguar, Pro Att, } \\
\text { Speed, Kodaci, Sankyo }\end{array}$ \\
\hline 5 & $\begin{array}{l}\text { Adidas, Dallas, New Era, Converse, Delta, } \\
\text { Nerro }\end{array}$ \\
\hline 6 & $\begin{array}{l}\text { Dallas, Rafila, Nike, Carvil, Ardiles, Inkayni, } \\
\text { Sankyo }\end{array}$ \\
\hline 7 & Adidas, Dallas,Converse, Levis, Yumeda \\
\hline 8 & $\begin{array}{l}\text { Rafila, Ando, Carvil, Vans, Pinard, Yumenda, } \\
\text { Tinker Bell, Inkayni }\end{array}$ \\
\hline 9 & Adidas, Nike, Converse, levis, Jaguar, Fuhaha \\
\hline 10 & $\begin{array}{l}\text { Dallas, New Era, Fila, Ardiles, Pro Att, Fuhaha, } \\
\text { HomiPed }\end{array}$ \\
\hline 11 & $\begin{array}{l}\text { Adidas, Dallas, Rafila, Ando, Nike, Carvil, Glass, } \\
\text { Ardiles, Lubrene, HomiPed, Inkayni }\end{array}$ \\
\hline 12 & $\begin{array}{l}\text { Adidas, Dallas, Rafila, Ando, New Era, Nike, } \\
\text { Converse, Romero, Ardiles, HomiPed, } \\
\text { Dellarosy, Roselina }\end{array}$ \\
\hline
\end{tabular}

Penelusuran database yang pertama digunakan untuk menghitung nilai support masing-masing item dan memilih yang memenuhi nilai minimum support. 
Tabel 5 Frequent dan Apriority

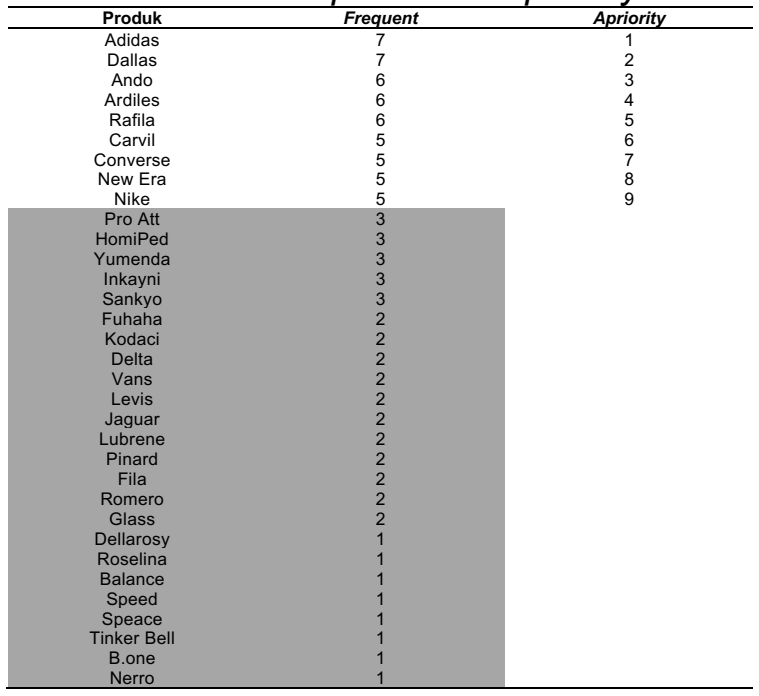

Kesembilan item ini akan berpengaruh saat pembuatan FP-Tree. Item yang Frequent kemunculnya dibawah minimum support count akan dihilangkan.

Tabel 6 Frequent List

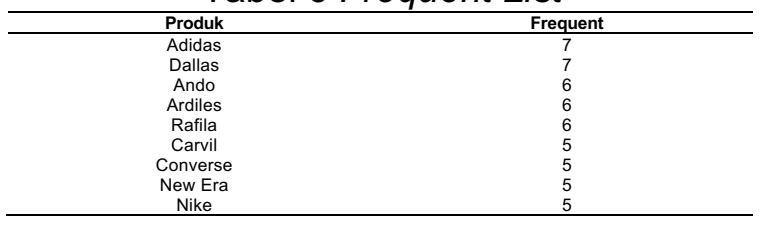

Setelah diperoleh Frequent List, kemudian item dirubah sesuai Frequent List dengan menghilangkan item yang tidak memenuhi minimum support yang ditentukan seperti item Vans, levis, Jaguar, Lubrene, Pinard, Pro Att, Fuhaha, HomiPed, Yumenda, Speed, Speace, Tinker Bell, Kodaci, B.one, Delta, Inkayni, Nerro, Fila, Romero, Glass, Dellarosy, Roselina dan Balance.

Tabel 7 Data transaksi yang sudah diurutkan berdasarkan frequent list

\begin{tabular}{cl}
\hline Bulan & \multicolumn{1}{c}{ Nama Produk } \\
\hline 1 & Adidas, Ando, Ardiles, Rafila, New Era, Carvil \\
2 & Dallas, Ando, Nike \\
3 & Adidas, Ardiles, New Era, Converse \\
4 & Ando, Rafila, Carvil \\
5 & Adidas, Dallas, New Era, Converse \\
6 & Dallas, Ardiles, Rafila, Nike, Carvil \\
7 & Adidas, Dallas, Converse \\
8 & Ando, Rafila, Carvil \\
9 & Adidas, Nike, Converse \\
10 & Dallas, Ardiles, New Era \\
11 & Adidas, Dallas, Ando, Ardiles, Rafila, Nike, \\
& Carvil \\
12 & Adidas, Dallas, Ando, Ardiles, Rafila, Converse, \\
& New Era, Nike
\end{tabular}

\section{Frequent Pattern-Tree (FP-Tree)}

Setelah item diurutkan berdasarkan prioritas, dilakukan penelusuran database yang kedua yaitu membaca tiap transaksi diawali dengan membaca TID 1 untuk membuat FP-Tree.

\section{A. Pembentukan TID 1}

TID 1 Adidas, Ando, Ardiles, Rafila, New Era Carvil\} akan membuat 6 simpul sehingga terbentuk lintasan seperti Gambar IV.1 dengan support count awal bernilai satu.

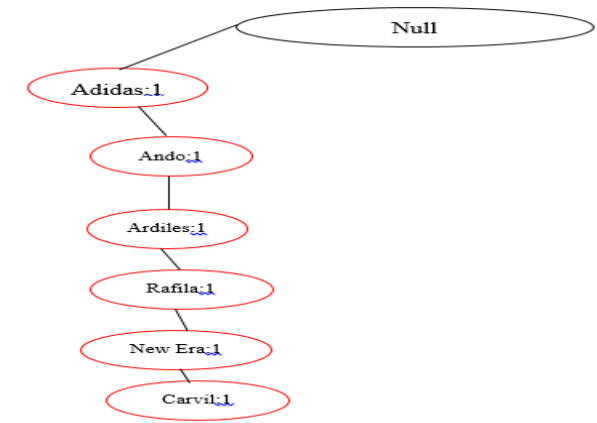

\section{Gambar 5 Hasil Pembentukan FP-Tree Setelah Pembacan TID 1}

B. Pembentukan TID 2

Setelah pembacaan TID 1, selanjutkan membaca TID 2 yaitu \{Dallas, Ando, Nike\}. Karena prefix Path (lintasan prefix) lintasannya tidak sama dengan lintasan sebelumnya, maka TID 2 dibuat lintasan baru.

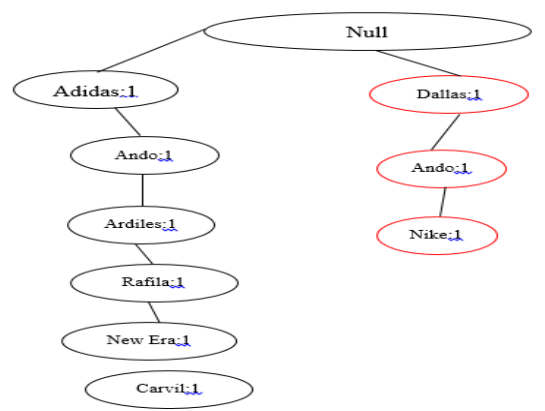

Gambar 6 Hasil Pembentukan FP-Tree Setelah Pembacan TID 2

C. Pembentukan TID 3

Setelah pembacaan TID 2, selanjutnya membaca TID 3 yaitu \{Adidas, Ardiles, New Era, Converse\}. Karena memiliki prefix Path (lintasan prefix) yang sama dengan lintasan TID 1 yaitu item adidas maka lintasan terbentuk pada TID 3 bisa dipadatkan pada 
lintasan TID 1. Setelah itu tambahkan support count pada item Adidas menjadi 2 karena telah dilewati sebanyak 2 kali dan lintasan baru untuk item Ardiles, New Era, Converse dengan support count bernilai satu.

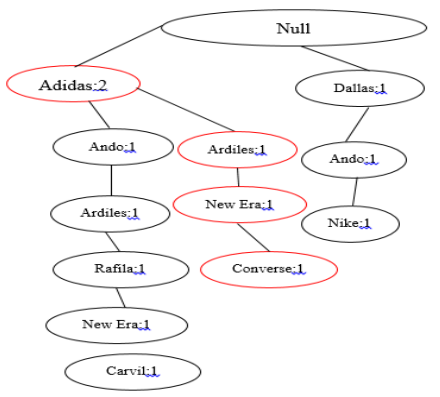

Gambar 7 Hasil pembentukan FP-Tree setelah pembacaan TID 3

Proses pembentukan FP-Tree terus dibuat sampai bulan ke 12 atau TID 12

\section{Pembentukan TID 12}

Setelah pembacaan TID 11, selanjutkan adalah pembacaan TID 12 yaitu \{Adidas, Dallas, Ando, Ardiles, Rafila, Converse, New Era dan Nike\}. Karena prefix Path (lintasan prefix) yang sama dengan lintasan TID 10 yaitu item Adidas, Dallas, Ando dan Rafila maka lintasan yang terbentuk pada TID 12 bisa dipadatkan pada lintasan TID 10. Setelah itu tambahkan support count pada item Adidas menjadi tujuh karena telah dilewati sebanyak tujuh kali, item Dallas menjadi empat karena telah dilewati sebanyak empat kali dan Ando, Ardiles, Rafila menjadi dua karena telah dilewati sebanyak dua kali kemudian membentuk lintasan untuk item Converse, New Era dan Nike dengan support count bernilai satu.

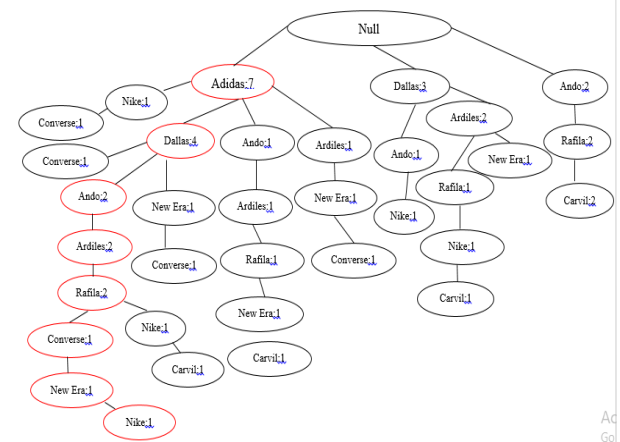

Gambar 8 Hasil pembentukan FP-Tree setelah pembacaan TID 12

\section{Frequent Pattern-Growth (FP-Growth)}

Setelah pembuatan FP-Tree selesai, FP-Growth mencari semua subsets yang memungkinkan dengan membangkitkan Conditional FP-Tree dan mencari Frequent Itemset

A. Kondisi FP-Tree untuk item Nike

Langkah Awal yaitu mengekstrak semua yang berakhiran Nike. Selain suffix pattern Nike diberi nilai 0 , hal ini dilakukan agar dapat mengetahui informasi berapa kali item yang dibeli bersamaan dengan item Nike dan bisa mengetahui frequent itemsets mana yang memenuhi syarat minimum support

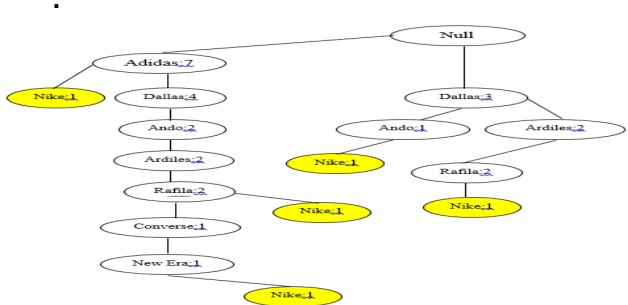

Gambar 9 Hasil pembentukan FP-Tree item Nike

Setelah melakukan ekstrak untuk lintasan yang berakhiran Nike, kemudian naikan suffix pattern satu persatu sampai menuju ke Root dan suffix pattern Nike dimasukan pada setiap suffix pattern yang dilintasi. Pada kondisi ini, item Converse dan New Era akan dihilangkan karena nilai kemunculannya secara bersamaan dengan item Nike hanya 1 kali. Sedangkan item Adidas, Dallas, Ando, Ardiles dan Rafila memiliki nilai kemunculan sebanyak lebih dari satu kali akan disimpan.

B. Kondisi FP-Tree untuk item New Era

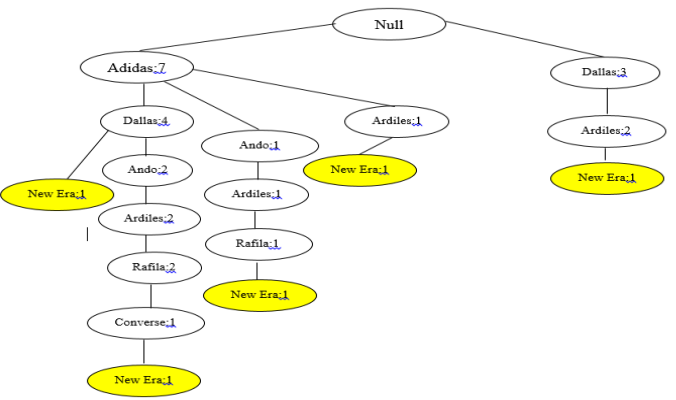

Gambar 10 Hasil Pembentukan FP-Tree item New Era 
Setelah melakukan ekstrak untuk lintasan yang berakhiran New Era, kemudian naikan suffix pattern satu persatu sampai menuju ke Root dan suffix pattern New Era dimasukan pada setiap suffix pattern yang dilintasi. Pada kondisi ini, item Converse akan dihilangkan karena nilai kemunculannya secara bersamaan dengan item Adidas dan New Era hanya 1 kali. Sedangkan item Dallas, Ando, Ardiles dan Rafila memiliki nilai kemunculan sebanyak lebih dari satu kali akan disimpan.

C. Kondisi FP-Tree untuk item Converse

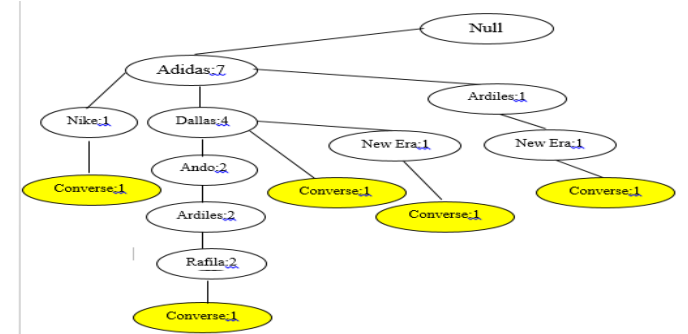

Gambar 11 Hasil Pembentukan FP-Tree item Converse

Setelah melakukan ekstrak untuk lintasan yang berakhiran Converse, kemudian naikan suffix pattern satu persatu sampai menuju ke Root dan suffix pattern Converse dimasukan pada setiap suffix pattern yang dilintasi. Pada kondisi ini, item Adidas, Dallas, Ando, Rafila dan Nike akan dihilangkan karena nilai kemunculannya secara bersamaan dengan item Converse hanya 1 kali. Sedangkan item Ardiles dan New Era memiliki nilai kemunculan sebanyak lebih dari satu kali akan disimpan

D. Kondisi FP-Tree untuk item Carvil

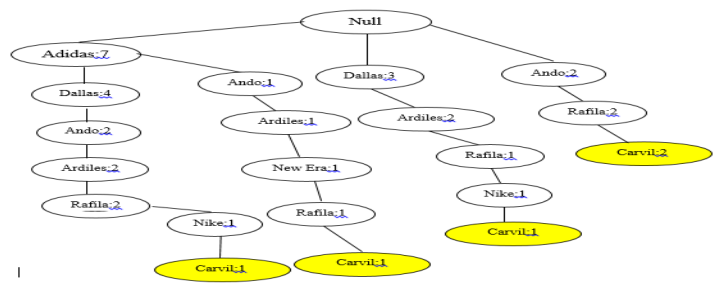

Gambar 12 Hasil pembentukan FP-Tree item Carvil

Setelah melakukan ekstrak untuk lintasan yang berakhiran Carvil, kemudian naikan suffix pattern satu persatu sampai menuju ke Root dan suffix pattern Carvil dimasukan pada setiap suffix pattern yang dilintasi. Pada kondisi ini, item Adidas akan dihilangkan karena nilai kemunculannya secara bersamaan dengan item Carvil hanya 1 kali. Sedangkan item Dallas, Ando, Ardiles Rafila dan Nike memiliki nilai kemunculan sebanyak lebih dari satu kali akan disimpan.

\section{E. Kondisi FP-Tree untuk item Rafila}

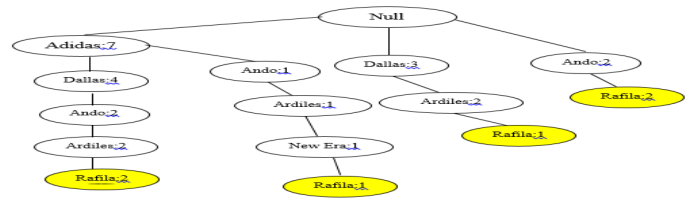

Gambar 13 Hasil pembentukan FP. Tree item Rafila

Setelah melakukan ekstrak untuk lintasan yang berakhiran Rafila, kemudian naikan suffix pattern satu persatu sampai menuju ke Root dan suffix pattern Rafila dimasukan pada setiap suffix pattern yang dilintasi. Pada kondisi ini, item New Era akan dihilangkan karena nilai kemunculannya secara bersamaan dengan item Rafila hanya 1 kali. Sedangkan item Adidas, Dallas, Ando dan Ardiles memiliki nilai kemunculan sebanyak lebih dari satu kali akan disimpan.

\section{F. Kondisi FP-Tree untuk item Ardiles}

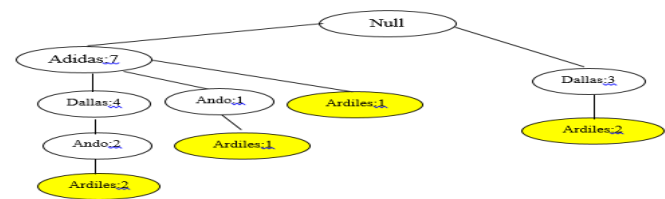

Gambar 14 Hasil pembentukan FPTree item Ardiles

Setelah melakukan ekstrak untuk lintasan yang berakhiran Ardiles, kemudian naikan suffix pattern satu persatu sampai menuju ke Root dan suffix pattern Ardiles dimasukan pada setiap suffix pattern yang dilintasi.

G. Kondisi FP-Tree untuk item Ando

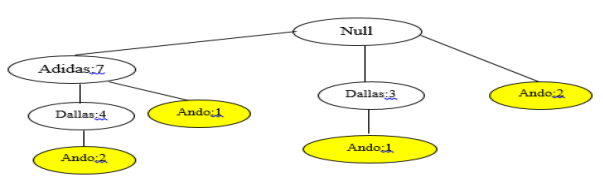

Gambar 15 Hasil pembentukan FP. Tree item Ando 
Setelah melakukan ekstrak untuk lintasan yang berakhiran Ando, kemudian naikan suffix pattern satu persatu sampai menuju ke Root dan suffix pattern Ando dimasukan pada setiap suffix pattern yang dilintasi.

H. Kondisi FP-Tree untuk item Dallas

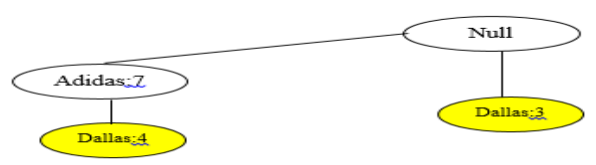

Gambar 16 Hasil pembentukan FP-Tree item Dallas

Setelah melakukan ekstrak untuk lintasan yang berakhiran Dallas, kemudian naikan suffix pattern satu persatu sampai menuju ke Root dan suffix pattern Dallas dimasukan pada setiap suffix pattern yang dilintasi.

I. Kondisi FP-Tree untuk item Adidas

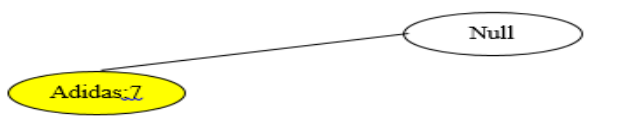

\section{Gambar 17 Hasil pembentukan FP-Tree item Adidas}

Pada kondisi ini, lintasan yang berakhiran item Adidas merupakan lintasan tunggal yang berdiri sendiri dan memiliki nilai Frequent adidas.

Setelah kondisi FP-tree untuk tiap-tiap item. Selanjutnya mencari Frequent itemset yang signifikan. Seperti pada penjelasan sebelumnya, Penerapan FP-Growth mengurutkan tiga langkah seperti

\section{A. Conditional Pattern Base}

Tabel 8 Conditional Pattern Base

\begin{tabular}{|c|c|}
\hline Suffix & Conditional Pattern Base \\
\hline Nike & $\begin{array}{l}\text { \{(Adidas, Dallas, Ando, Ardiles, Rafila, Converse, New Era:1),(Adidas, } \\
\text { Dallas, Ando, Ardiles, Rafia:1),(Adidas:1),(Dallas, Ando:1),(Dallas, Ardiles, } \\
\text { Rafila:1)\} }\end{array}$ \\
\hline New Era & $\begin{array}{l}\{(\text { Addidas, Dallas, Ando, Ardiles, Rafila, Converse:1),(Adidas, Ando, Ardiles, } \\
\text { Rafila:1),(Adidas, Dallas:1),(Adidas, Ardiles:1),(Dallas, Ardiles:1)\} }\end{array}$ \\
\hline Converse & 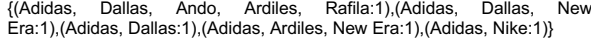 \\
\hline Carvil & 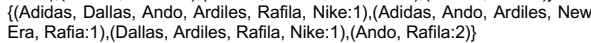 \\
\hline Rafila & $\begin{array}{l}\{(\text { Adidas, Dallas, Ando, Ardiles:2),(Adidas, Ando, Ardiles, New Era:1),(Dallas, } \\
\text { Ardiles:1),(Ando:2)\} }\end{array}$ \\
\hline $\begin{array}{l}\text { Ardiles } \\
\text { Ando }\end{array}$ & $\begin{array}{l}\{\text { (Adidas, Dallas, Ando:2),(Adidas, Ando:1),(Adidas:1),(Dallas:2)\} } \\
\{\text { (Adidas, Dallas:2),(Adidas:1),(Dallas:2)\}}\end{array}$ \\
\hline Dallas & $\{($ Adidas:4) $\}$ \\
\hline
\end{tabular}

Untuk mencari Conditional FP-Tree adalah dengan cara menjumlahkan Support Count yang ada dan Support Count yang lebih besar akan dibangkitkan dengan Conditional FP-Tree. Berikut tabel hasil Conditional FP-Tree:

B. Conditional Pattern Tree

Tabel 9 Conditional Pattern Tree

\begin{tabular}{lll}
\hline \multicolumn{1}{c}{ Suffix } & & Conditional FP-Tree \\
\hline Nike & \{(Dallas:4)\} & \\
New Era & (Adidas, Ardiles:4)\} & \\
Converse & \{(Adidas:5)\} & \\
Carvil & \{(Ando:4), (Rafila:5)\} & \\
Rafila & (Ardiles:4), (Ando:5)\} \\
Ardiles & (Adidas: Dallas:4)\} \\
Ando & (Dallas:4)\} & \\
Dallas & \{(Adidas:4)\} \\
\hline
\end{tabular}

Setelah mencari Conditional FP-tree maka tahapan yang selanjutnya adalah mencari Frequent Pattern Generated. Dimana tahapan ini mencari single path kemudian dikombinasikan dengan item yang ada pada Conditional FP-Tree.

C. Frequent Pattern Generated

Tabel 10 Frequent Pattern Generated

\begin{tabular}{|c|c|}
\hline \multirow{2}{*}{\multicolumn{2}{|c|}{ Frequent Pattern Generated }} \\
\hline & \\
\hline New Era & $\{$ (Adidas,New Era:4)\},\{(Ardiles,New Era:4)\} \\
\hline Converse & $\{$ (Adidas, Converse:5)\} \\
\hline $\begin{array}{l}\text { Carvil } \\
\text { latse }\end{array}$ & $\{($ Ando, Carvil:4) $)\},\{($ Rafila, Carvil:5) $\}$ \\
\hline Rafila & $\{($ Ardiles, Rafila:4) 4$\}\{$ (Ando, Rafila:5)\} \\
\hline Ardiles & $\{($ Adidas, Ardiles: 4$)\},\{($ Dallas, Ardiles:4)\} \\
\hline Ando & $\{($ Dallas, Ando: 4$)\}$ \\
\hline Dallas & $\{($ Adidas, Dallas:4)\} \\
\hline
\end{tabular}

Gambar berikut ini hasil dari Frequent Itemset:

Tabel 11 Frequent Itemset

\begin{tabular}{c} 
Frequent Itemset \\
$\{($ Adidas, Converse:5)\} \\
$\{($ Rafila, Carvil:5) $\}$ \\
$\{($ Ando,Rafila:5 $)\},\{($ Carvil,Rafila:5 $)\}$ \\
\hline
\end{tabular}

\section{Association Rules}

Setelah mendapatkan Frequent Pattern Generated, tahapan berikutnya mencari nilai Support $>40 \%$ dan Confidence $>83 \%$, dengan Kombinasi 2 itemset dan Pembentukan Aturan Asosiasi

\section{A. Kombinasi 2 itemset}

Proses pembentukan $\mathrm{C}_{2}$ atau disebut dengan 2 itemset dengan jumlah Minimum Support $=40 \%$.

\section{Dallas dan Nike}

$$
\begin{aligned}
& \text { S (Dallas dan Nike) } \frac{4}{12} X 100=33,33 \\
& \text { S (Nike dan Dallas) } \frac{4}{12} X 100=33,33
\end{aligned}
$$


2. Adidas dan New Era

$S$ (Adidas dan New Era) $\frac{4}{12} \mathrm{X} 100=33,33$

$\mathrm{S}$ (New Era dan Adidas) $\frac{4}{12} \mathrm{X} 100=33,33$

3. Ardiles dan New Era

$S$ (Ardiles dan New Era) $\frac{4}{12} \mathrm{X} 100=33,33$

$S$ (New Era dan Ardiles) $\frac{4}{12} \times 100=33,33$

4. Adidas dan Converse

S (Adidas dan Converse) $\frac{5}{12} \mathrm{X} 100=41,66$

S (Converse dan Adidas) $\frac{5}{12} \mathrm{X} 100=41,66$

5. Ando dan Carvil

S (Ando dan Carvil) $\frac{4}{12} \mathrm{X} 100=33,33$

S ( Carvil dan Ando) $\frac{4}{12} \times 100=33,33$

6. Rafila dan Carvil

S (Rafila dan Carvil) $\frac{5}{12} \mathrm{X} 100=41,66$

S (Carvil dan Rafila) $\frac{5}{12}$ X100 $=41,66$

7. Ardiles dan Rafila

$S$ (Ardiles dan Rafila) $\frac{4}{12} X 100=33,33$

S (Rafila dan Ardiles) $\frac{4}{12} \times 100=33,33$

8. Ando dan Rafila

S (Ando dan Rafila) $\frac{5}{12} \mathrm{X} 100=41,66$

S (Rafila dan Ando) $\frac{5}{12} \mathrm{X} 100=41,66$

\section{B. Pembentukan Aturan Asosiasi}

Setelah semua pola frekuensi tinggi ditemukan, baru dicari aturan asosiasi yang memenuhi syarat Minimum Confidence dengan menghitung Confidence aturan asosiatif $A \rightarrow B$ dan $B \rightarrow A$.

1. Adidas dan Converse

C (Adidas dan Converse) $\frac{5}{7} \mathrm{X} 100=71,42$

C (Converse dan Adidas) $\frac{5}{5} \mathrm{X} 100=100$

2. Rafila dan Carvil

C (Rafila dan Carvil) $\frac{5}{6}$ X100 $=83,33$

C (Carvil dan Rafila) $\frac{5}{5}$ X100 $=100$

3. Ando dan Rafila
C (Ando dan Rafila) $\frac{5}{6} \mathrm{X} 100=83,33$
C (Rafila dan Ando) $\frac{5}{6} \mathrm{X} 100=83,33$

Setelah mendapatkan nilai Support > 40\% dan Confidence > 83\%, Tahapan berikutnya membuat Association Rules.

Tabel 12 Association Rules

\begin{tabular}{cccc}
\hline $\begin{array}{c}\text { Jika } \\
\text { Membeli } \\
\text { Produk }\end{array}$ & $\begin{array}{c}\text { Maka Akan } \\
\text { Membeli } \\
\text { Produk }\end{array}$ & Support & Confidence \\
\hline Converse & Adidas & $41,66 \%$ & $100 \%$ \\
Carvil & Rafila & $41,66 \%$ & $100 \%$ \\
Rafila & Carvil & $41,66 \%$ & $83,33 \%$ \\
Rafila & Ando & $41,66 \%$ & $83,33 \%$ \\
Ando & Rafila & $41,66 \%$ & $83,33 \%$ \\
\hline
\end{tabular}

Tabel Association Rules diatas kemudian akan dibentuk Rules akhir yang termasuk Strong Association Rule yang memiliki nilai Support $40 \%$ dan Confidence $83 \%$ dapat dilihat pada tabel berikut:

\section{Tabel 13 Strong Rules}

\begin{tabular}{|c|c|c|}
\hline $\begin{array}{r}\text { Strong Rule } \\
\end{array}$ & Support & Confidence \\
\hline $\begin{array}{l}\text { Jika membeli produk Converse, Maka akan membeli produk } \\
\text { Adidas }\end{array}$ & $41,66 \%$ & $100 \%$ \\
\hline $\begin{array}{l}\text { Jika membeli produk Carvil, Maka akan membeli produk } \\
\text { Rafila }\end{array}$ & $41,66 \%$ & $100 \%$ \\
\hline $\begin{array}{l}\text { Jika membeli produk Rafila, Maka akan membeli produk } \\
\text { Carvil }\end{array}$ & $41,66 \%$ & $83,33 \%$ \\
\hline $\begin{array}{l}\text { Jika membeli produk Rafila, Maka akan membeli produk Ando } \\
\text { Jika membeli produk Ando, Maka akan membeli produk Rafila }\end{array}$ & $\begin{array}{l}41,66 \% \\
41,66 \%\end{array}$ & $\begin{array}{l}83,33 \% \\
83,33 \% \\
\end{array}$ \\
\hline
\end{tabular}

\section{Percobaan dan Pengujian}

Untuk pengujian dari data transaksi penjualan sepatu dan sandal yang telah dihasilkan berupa pola kombinasi antar item dan Association Rules sesuai dengan FPGrowth. Maka digunakan aplikasi Rapidminer 5 untuk pengujian analisa pembelian sepatu dan sandal yang dilakukan oleh konsumen.

Adapun langkah-langkah pembentukan model mining menggunakan FP-Growth pada Software Rapidminer antara lain:

A. Memilih file format xls yang akan dimining.

B. yang digunakan FP-Growth.

C. Mengatur Minimum Support, Confidence dan Rules yang dihasilkan.

Evaluasi data mining akan dilakukan dengan menggunakan Dataset pengujian yang berisikan 9 transaksi penjualan sepatu dan sandal yang akan dilakukan perhitungan menggunakan FP-Growth. Langkah kedua 
Dataset akan dijalankan melalui model mining yang dibuat pada Rapidminer 5 .

\section{A. Proses Koneksi}

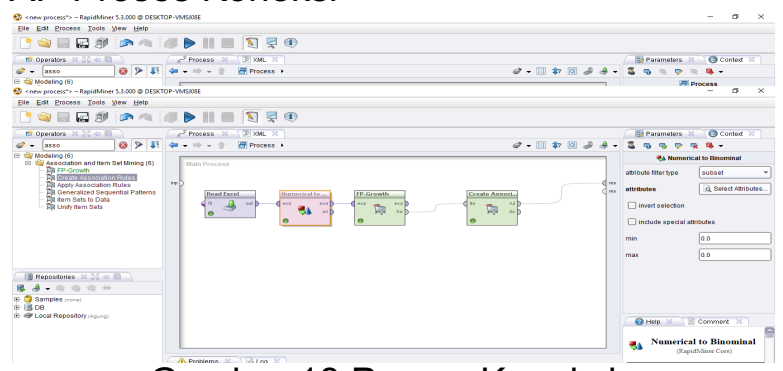

Gambar 18 Proses Koneksi

Pada tahap ini digunakan untuk menentukan nilai Support dan Confidence pada setiap Itemset dengan rumus yang sudah dijelaskan sebelumnya pada landasan teori. Pada kasus diatas, misalkan diberikan nilai Minimum Support $=0.40$ dan Minimum Confidence $=0.83$ maka hasilnya adalah:

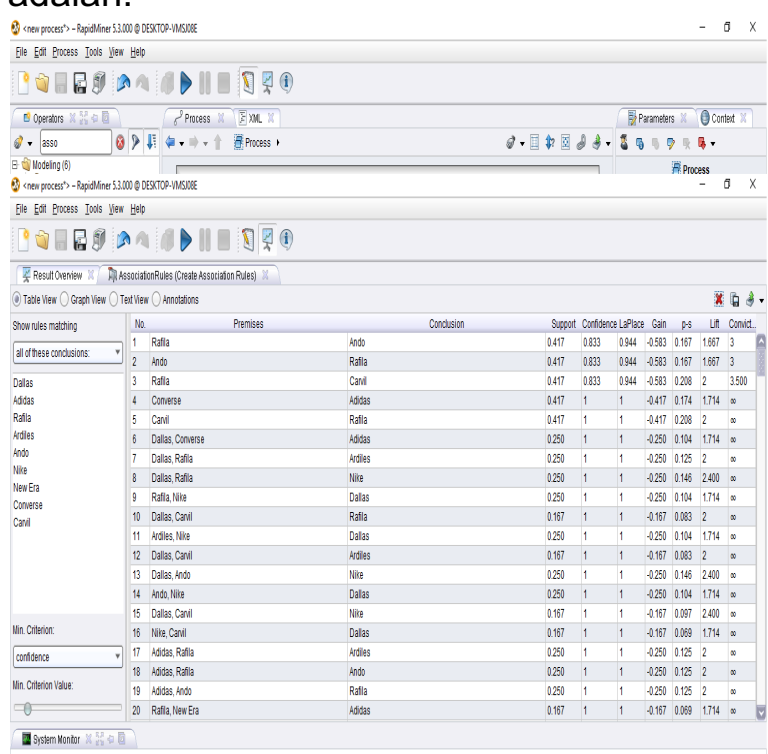

Gambar 19 Hasil Frequent Itemset

B. Hasil Association Rules

Maka hasil dari perhitungan menggunakan RapidMiner 5 menghasilkan 5 Rules. Hasil yang didapat dari Association Rules (Text View) juga menjelaskan bahwa item A dan B saling berkaitan dengan menjelaskan secara Text. Hasil perhitungan diatas berbeda dengan perhitungan data sampel.

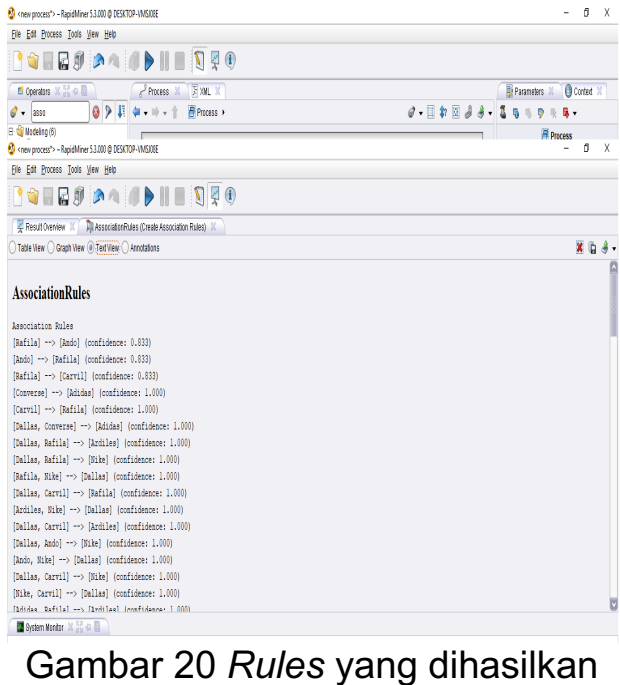

Dari pengolahan data pada gambar 20 yang dilakukan proses perhitungan menggunakan RapidMiner didapatkan jumlah aturan aturan asosiasi sebanyak 5 rule dengan jumlah minimum support $40 \%$ dan jumlah Minimum Confidence $83 \%$.

\section{Implementasi}

A. Tampilan Home

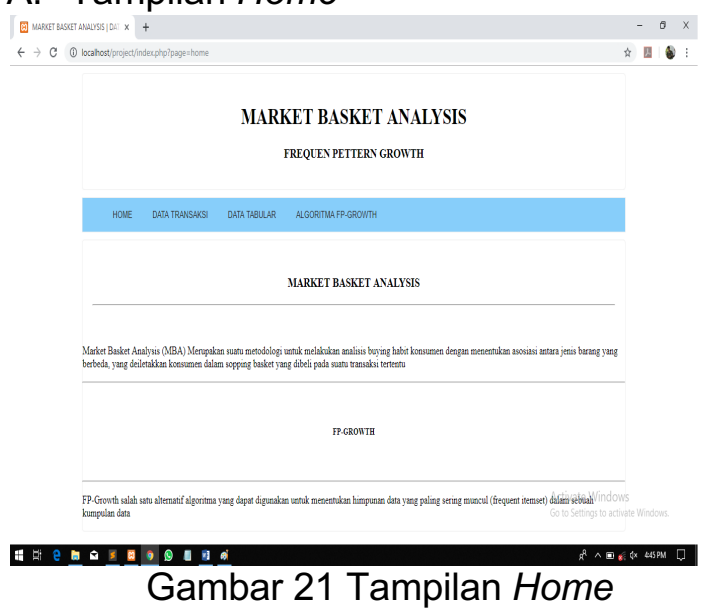

B. Tampilan Input Data Transaksi

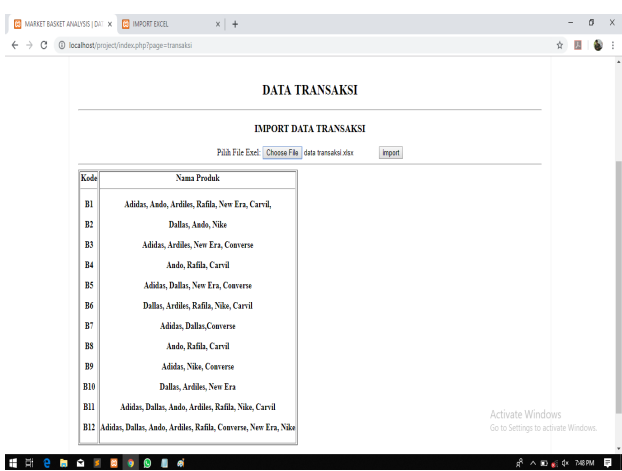

Gambar 22 Tampilan Input Data Transaksi 
C. Tampilan Input Data Tabular

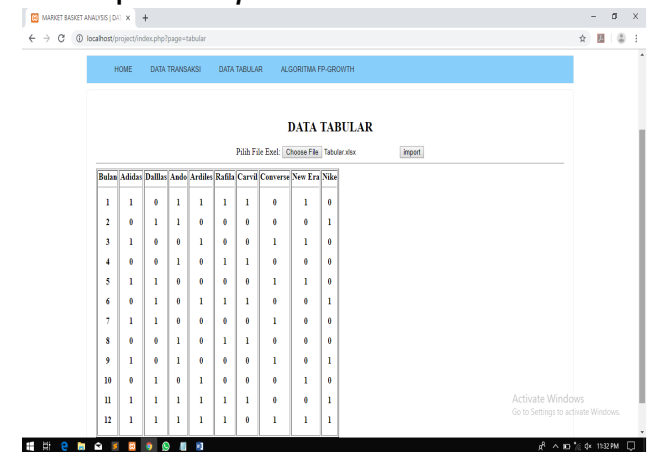

Gambar 23 Tampilan Input Data Tabular

D. Tampilan Input Support dan Confidence

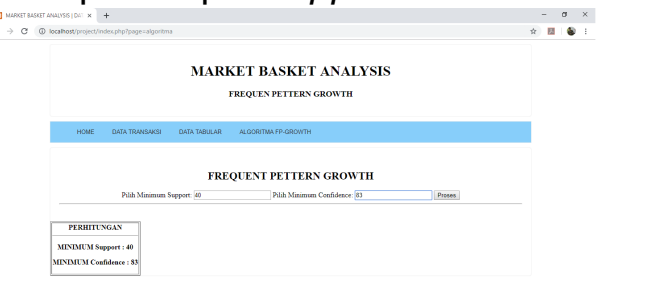

Gambar 24 Input support dan Confidence

\section{E. Tampilan Hasil Association Rules}

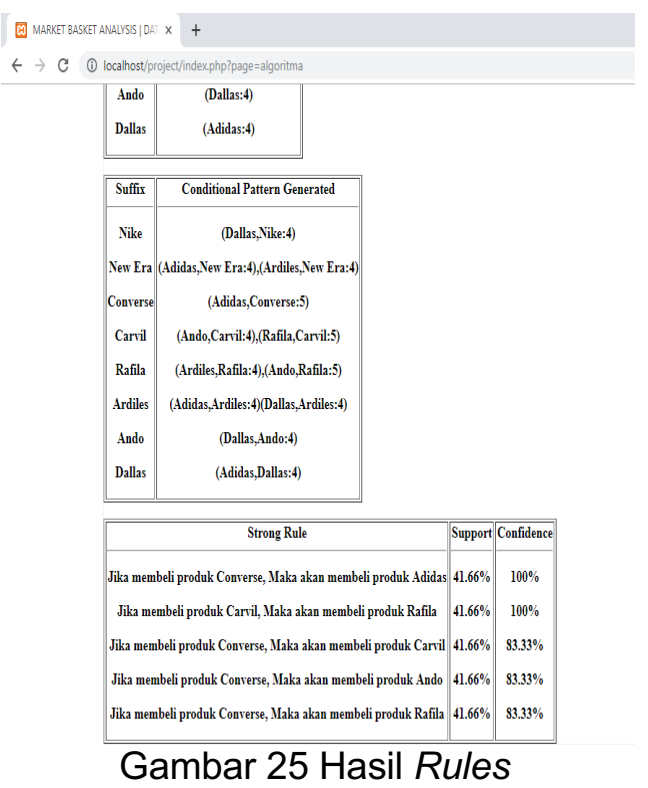

Dari hasil penilitian di atas maka dapat dilakukan analisis bahwa produk sandal dan sepatu yang diminati oleh konsumen PD Pasar Tohaga, diantaranya: produk dengan merk sepatu atau sandal Converse dan Carvil. Jika konsumen membeli produk converse, maka kemungkinan besar akan membeli produk adidas. Dan jika konsumen membeli produk sepatu dan sandal carvil maka konsumen akan membeli produk Rafila. Sehingga disarankan kepada pemilik usaha Toko Reka, Toko Fernando dan Toko Son pada PD Pasar Tohaga untuk selalu menyediakan produk sepatu atau sandal seperti Adidas, Rafila, Carvil, dan Converse. Selain itu direkomendasikan produk sandal atau sepatu anda untuk dijual karena masih cukup diminati oleh konsumen.

\section{SIMPULAN \\ Kesimpulan}

Dari hasil penelitian yang dilakukan tentang Penerapan Data Mining untuk Analisis Market Basket dengan FP-Growth pada PD PASAR TOHAGA. Penulis memberi Kesimpulan sebagai berikut:

Hasil penjualan dari produk sepatu dan sandal yang paling banyak terjual di Toko Reka, Toko Fernando dan Toko Son bisa diketahui dengan menggunakan FPGrowth. Sepatu dan sandal yang memenuhi Minimum Support dan Minimun Confidence serta yang banyak terjual adalah Adidas, Ando, Rafila, Carvil, dan Converse.

Menerapkan Metode Data Mining dengan FP-Growth untuk analisis pola pembelian konsumen sangat bermanfaat bagi pihak toko, karena bisa mengetahui merk produk sepatu dan sandal yang paling banyak dibeli dan membantu dalam pemesanan sepatu dan sandal pada pemilik toko. Kemudian memberikan masukan ke pemilik toko untuk menempatkan rak produk converse dekat dengan produk adidas dan menempatakn rak produk carvil dekat dengan produk rafila

\section{Saran}

Dari kesimpulan diatas, penulis memberikan beberapa saran yang dapat diperhatikan untuk penelitian dalam pengembangan selanjutnya, yaitu:

Dalam implementasi data ini, jika semakin besar data yang diambil, maka akan mendapatkan hasil yang lebih akurat dan lebih besar juga. Jika dilakukan pengembangan terhadap penelitian ini, sebaiknya dilakukan penambahan sampel. 
Dalam penempatan produk dengan merk dan jenis, agar pihak konsumen lebih jelas melihat produk, hal ini berguna untuk memudahkan konsumen dalam pembelian dan karyawan toko lebih mudah mencari produk yang disukai konsumen.

Software pengujian yang digunakan dalam penelitian ini yaitu RapidMiner, selain itu bisa menggunakan Aplikasi Data Mining lainnya seperti TANAGRA untuk pencarian Frequent Itemset dalam menentukan Minimum Support. kemudian bisa juga memakai aplikasi WEKA.

\section{REFERENSI}

[1] Alfanisa, A. F., \& Algifanri, M. Penerapan Data Mining untuk Analisis Pola Pembelian Konsumen dengan

FP-GROWTH pada Data Transaksi Penjualan. Ilmu Komputer. 2018: 05(01): 27-36.

[2] Icca, A., Muhammad, Z. A., \& Utomo, P. Penerapan FP-Growth Dalam Penentuan Pola Pembelian Konsumen Pada Kain Tenun Medali Mas. Jurnal Matrix. 2019: 9(1): 32-40.

[3] Elwani. (2017). Penentuan Aturan Asosiasi pada Transaksi Peminjaman Buku menggunakan FP-GROWTH. 9(1), 15-25.

[4] Ida, A. S. P., \& Luh,P. P. S. P. Analisis Pola Kunjungan Obyek Wisata di Bali menggunakan FP-GROWTH. Media Aplikom. 2018: 10(2): 158-177.

[5] Deni, R., \& Agus, S. FP-GROWTH dalam Penempatan Lokasi Barang di Gudang PT. XYZ. Jurnal IImu Pengetahuan Dan Teknologi Komputer. 2018: 4(1): 63-70.

[6] Ali, I., Dicky, N., \& Sriani. (2015). Penerapan Data Mining dengan Algoritma Fp-Growth untuk Mendukung Strategi Promosi Pendidikan (Studi Kasus Kampus STMIK Triguna Dharma). 14(03). Diambil dari http:// ejournal.undhari.ac.id/ index.php/ simtika/ article/ download/3/ 2/

[7] Chandra, E. F. (2017). Penentuan Pola yang sering muncul untuk Penjualan Pupuk menggunakan Algoritma FPGROWTH. 9(2), 1-8. Diambil dari http:// ejournal.stmikdumai.ac.id/ index.php/ path/ article/ view/ 97

[8] Eka, L. F., \& Suryadi, S. (2018). Penerapan Data Mining dengan Algoritma Apriori. STMIK Royal-AMIK Royal, 173-176. Diambil dari http:// jurnal.stmikroyal.ac.id/ senar/ issue/ view/ 6 index.php/

[9] Erma, D. S. (2018). Penerapan Data Mining Penjualan Sepatu Menggunakan Metode Algoritma Apriori. 4(1), 156-161. Diambil dari https:// ejournal.bsi.ac.id/ ejurnal/ index.php/ jtk/ article/ view/ 2560

[10] Mateus, P. T., Fitri, M., \& Indra, D. W. (2018). Penerapan Metode Data Mining Market Basket Analysis Terhadap Data Penjualan Produk Pada Toko Oase Menggunakan Algoritma Apriori. 3(2), 17-22. Diambil dari http:// ejurnal.unmerpas.ac.id/ index.php/ informatika/ article/ view/ 167 